\title{
Impact of climate variability and change on crop production in Maharashtra, India
}

\author{
Saurabh M. Kelkar ${ }^{1, *}$, Ashwini Kulkarni ${ }^{2}$ and K. Koteswara Rao ${ }^{2}$ \\ ${ }^{1}$ Department of Atmospheric and Space Sciences, Savitribai Phule Pune University, Pune 411 007, India \\ ${ }^{2}$ Indian Institute of Tropical Meteorology, Dr. Homi Bhabha Road, Pashan, Pune 411 008, India
}

\begin{abstract}
This study estimates the possible effects of change in climatic factors on the production of major crops in Maharashtra, India. Daily precipitation, and minimum and maximum temperature simulated by a statistically downscaled MPI-ESM-MR model in NEXGDDP archive have been used in the study. Under RCP4.5, the analysis suggests a significant reduction in the production of three major crops, viz. sugarcane, cotton and rice. This decline is prominent in central and central-east Maharashtra. These findings imply the need to improve and develop new seed varieties that can withstand drastic changes in climate and also give high yield to combat food security of an increasing population.
\end{abstract}

Keywords: Climate variability and change, crop production projections, food security, regression.

AN imminent change in climate is the increase in global atmospheric temperature due to increased levels of greenhouse gases ${ }^{1}$. In India, several studies have shown that unprecedented warming in surface temperature has occurred during the last century ${ }^{1-8}$. However, there is no significant trend in seasonal rainfall on the all-India scale $^{6,9-12}$, in spite of a slight decrease in all-India rainfall post-1950s. The global mean temperatures have increased by $0.8^{\circ} \mathrm{C}$ compared to the last century ${ }^{13}$. The world's current population is about 7.3 billion; it is expected to reach 9.7 billion by 2050 and 11.2 billion by 2100 (ref. 14). For food security of the tremendously increasing population, food production must increase multiple fold compared to the current output by 2100 . The South Asian region, as well as the Indian region, is densely populated, economically weak and life of the people highly depends on agriculture which is vulnerable to impacts of climate change. According to the UN report ${ }^{14}$, the population of India may rise to 1.66 billion by 2050 . Based on several studies, covering many regions and crops, the adverse effects of climate change on crop production have been more common than positive impacts ${ }^{15}$. Crops are highly sensitive to temperature in all stages of their life cycle. As temperature increases, crop development accelerates which causes the plant to mature early. The conversion of

*For correspondence. (e-mail: kelkarsaurabh527@gmail.com) sucrose to starch, which ensures the grain number and grain weight, decreases with increases in temperature. In other words, it affects the production of dry mass, grain growth and ultimately reduces grain yield ${ }^{16}$. Effects of warmer temperature are most striking when heat stress occurs during the flowering period. In rice, heat stress during flowering reduces pollination and grain numbers ${ }^{17,18}$. Higher temperatures entail a higher evaporative demand. Therefore, the regions with sufficient soil moisture, such as the irrigated lands, it could lead to soil salinization ${ }^{19}$. In tropical monsoon climate, an increase in the number of rainfall events and increase in total precipitation would increase leaching rates in well-drained soils and cause temporary water saturation and hence reduced organic matter decomposition ${ }^{20}$.

The agriculture sector is more vulnerable to changing climate compared to other sectors ${ }^{15}$. The extent to which changes in climate variables affect crop production is essential for devising proper policies and management systems to manage increasing demands ${ }^{21}$. The impact of climate change on crop yield can be estimated using two methods - crop simulation models and statistical models. Crop simulation (agronomic) modelling simulates crop growth as a function of different climate and soil conditions $^{22-25}$. Statistical models such as regression models use the relationship between crop yield, soil parameters, climate/weather variables and trend parameters ${ }^{26}$.

The present study utilizes statistical methods to assess the impact of climate change on crop production in Maharashtra, India. The assessment includes analysis at spatial scales of subdivision and district.

\section{Study area}

Area-wise Maharashtra is the third largest state and has a very large share in total crop production in India. It is further divided into four meteorological subdivisions, viz. Konkan-Goa, Madhya Maharashtra, Marathwada and Vidarbha (Figure 1). There is significant variation in the spatial distribution of rainfall within different parts of Maharashtra. Konkan-Goa in the Western Ghats is a high rainfall region. Madhya Maharashtra and Marathwada receive less rainfall compared to Konkan and Vidarbha, primarily due to their position in the rain shadow region of the Western Ghats ${ }^{27}$. 


\section{RESEARCH ARTICLES}

The mean annual rainfall of the state is $1363 \mathrm{~mm}$, with a standard deviation of $118.9 \mathrm{~mm}$. Figure $2 a-c$ shows the inter-annual variability of annual rainfall, minimum temperature and maximum temperature respectively. The average annual minimum temperature of Maharashtra is $15.05^{\circ} \mathrm{C}$ (Figure $2 \mathrm{~b}$ ) and average annual maximum temperature is $30.3^{\circ} \mathrm{C}$ (Figure $2 c$ ), with a standard deviation of $0.97^{\circ} \mathrm{C}$ and $1.25^{\circ} \mathrm{C}$ respectively.

Throughout the state, several crops are grown, but sugarcane, cotton and rice that are cultivated in the kharif season, are the major crops with high economic value (Figure 3). Rice production is the highest in the Konkan and east Vidarbha region with a total area of cultivation of 1.4714 million hectares ( $\mathrm{m} \mathrm{ha}$ ), while $0.9868 \mathrm{~m}$ ha of area which includes Madhya Maharashtra and Marathwada is under sugarcane cultivation. Cotton is the main crop in West Vidarbha and some parts of Marathwada with an area of $4.2069 \mathrm{~m}$ ha under cultivation ${ }^{28}$. The average annual rice production in Maharashtra is 3.6 million tonnes $(\mathrm{mt})$, while sugarcane production is $72.26 \mathrm{mt}$, sharing $20.52 \%$ of the all-India production. Cotton contributes $21.56 \%$ with an annual production of 6.5 million bales $(1 \text { bale }=170 \mathrm{~kg})^{28}$.

\section{Primary crops}

\section{Sugarcane}

This is a tropical crop, and under warm and humid conditions continues its growth unless terminated due to flowering. A typical life cycle of sugarcane is around 15-18 months ${ }^{29}$. Maximum temperature of $27^{\circ}-38^{\circ} \mathrm{C}$ is essential during all phases of its growth. For germination, optimum temperature of $32^{\circ}-38^{\circ} \mathrm{C}$ is required. Above $38^{\circ} \mathrm{C}$, rate of photosynthesis decreases ${ }^{29}$. A sufficient amount of water is also equally essential for development of the crop.

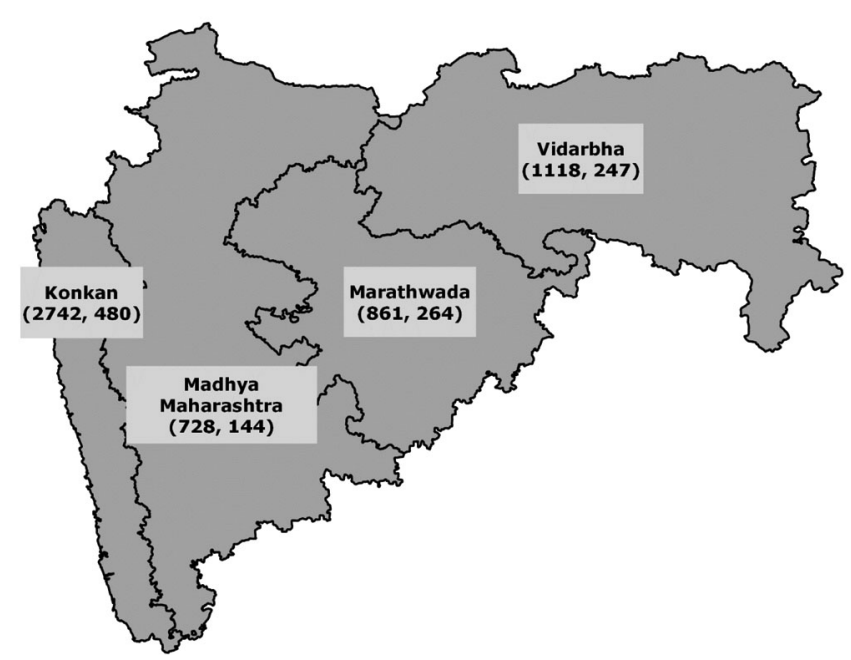

Figure 1. Meteorological subdivisions of Maharashtra. Mean annual rainfall, standard deviation $(\mathrm{mm})$ are also given.
Compared to rice and cotton, sugarcane, which takes almost a year to mature, requires more water for growth. During the developmental phase, a large amount of rainfall is desirable; however, as crop growth advances, the water requirement is reduced ${ }^{29}$. Irrigation is implemented in low-rainfall regions to provide sufficient water for sugarcane. It has been observed that though sugarcane requires a large amount of water, a large area of the semiarid, drought-prone region like Marathwada $(\sim 1.5 \mathrm{~m} \mathrm{ha})$ has been brought under sugarcane cultivation by irrigation $^{30}$. Figure $4 a$ shows sugarcane production over Maharashtra during the study period.

\section{Cotton}

This is grown in a semi-arid climate and requires a mean temperature of $21^{\circ}-27^{\circ} \mathrm{C}$ for proper vegetative growth. With adequate soil moisture, it can tolerate temperatures as high as $43^{\circ} \mathrm{C}$, but below $21^{\circ} \mathrm{C}$ the growth slows down or ceases. Cotton requires $600-1000 \mathrm{~mm}$ of rainfall during its entire growth phase; however, heavy rainfall or moisture stress during bud development and boll shedding will substantially reduce the yield. Cotton is also called 'white gold' because of its economic value in the market. Figure $4 b$ shows the time series of cotton production over Maharashtra. The sudden boost in production after 2005 was due to the large-scale commercial cultivation of high-yielding varieties.

\section{Rice}

This crop needs a hot and humid climate. It is cultivated in the areas of high humidity, prolonged sunshine, an assured supply of water and requires 4-6 months for full growth. The average temperature required for rice crop development is $20^{\circ}-40^{\circ} \mathrm{C}$. The optimum temperature of $30^{\circ} \mathrm{C}$ during daytime and $20^{\circ} \mathrm{C}$ during night-time are favourable for growth and development of the crop. When the temperature is in the critical range, rainfall is the most crucial factor for cultivation of rice crops. Rainfed rice cultivation is limited to areas where rainfall is more than $1000 \mathrm{~mm}$. Even though high rainfall is preferred, variation in the distribution of rainfall is the most critical factor $^{29}$. Figure $4 c$ shows the rice production time series over Maharashtra. Throughout the years, total production has increased due to chemical fertilizers, advanced machinery, etc.

\section{Data and methodology}

\section{Data}

(i) Monthly rainfall for 29 meteorological subdivisions over India for the period 1871-2016 which have been 

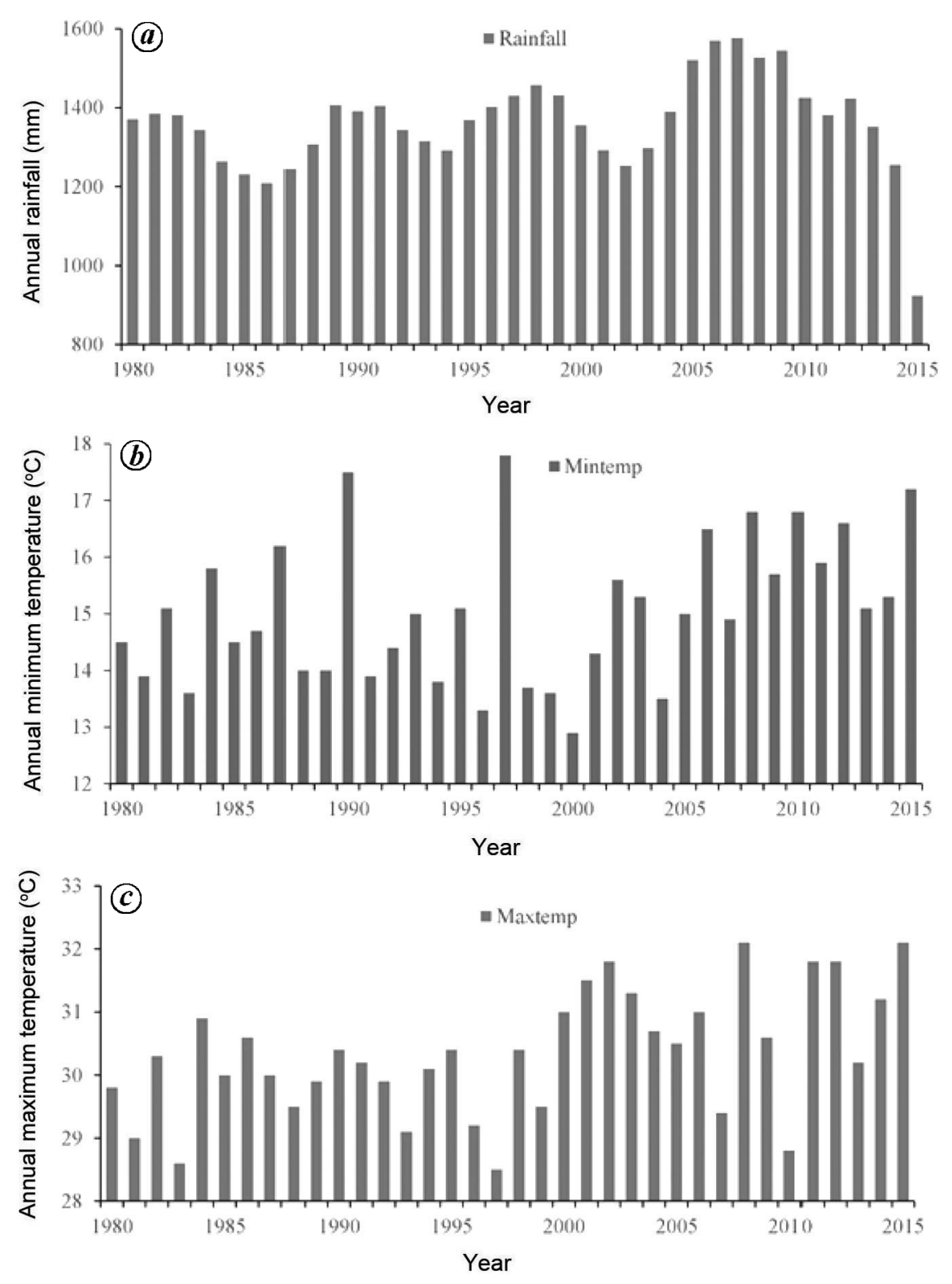

Figure 2. Time series of $(\boldsymbol{a})$ annual rainfall $(\mathrm{mm}),(\boldsymbol{b})$ mean annual minimum temperature $\left({ }^{\circ} \mathrm{C}\right)$, and $(\boldsymbol{c})$ mean annual maximum temperature $\left({ }^{\circ} \mathrm{C}\right)$ for Maharashtra during 1980-2015.

archived at the Indian Institute of Tropical Meteorology, Pune (www.tropmet.res.in) are used in this study. The annual rainfall for each of the four subdivisions of Maharashtra for the period 1980-2015 has been used here since crop production data are available for this period. The annual rainfall for Maharashtra was computed by simple average of the annual rainfall over these four subdivisions. The monthly rainfall for 36 districts of Maharashtra and daily high-resolution gridded $\left(1^{\circ} \times 1^{\circ}\right)$ minimum and maximum temperature data over India for the period 1951-2015 have been obtained from the India Meteorological Department, Pune. Since all the grids are of the same size, the annual average maximum and average minimum temperature over Maharashtra as well as its districts have been computed with a simple average of daily maximum and minimum temperature over the corresponding grids. We consider annual rainfall and annual maximum and minimum temperatures to examine the impact of variability in these two climate parameters on crop production.

(ii) In this study, the annual crop production data for rice, sugarcane, and cotton for Maharashtra during 19802015 have been used. In 1980, Maharashtra had 30 districts; however, some of these districts bifurcated at various points in time and thus there were 36 districts in 2015. The data from newly formed districts were aggregated into the original 30 districts to construct a consistent dataset. The annual crop production data for 


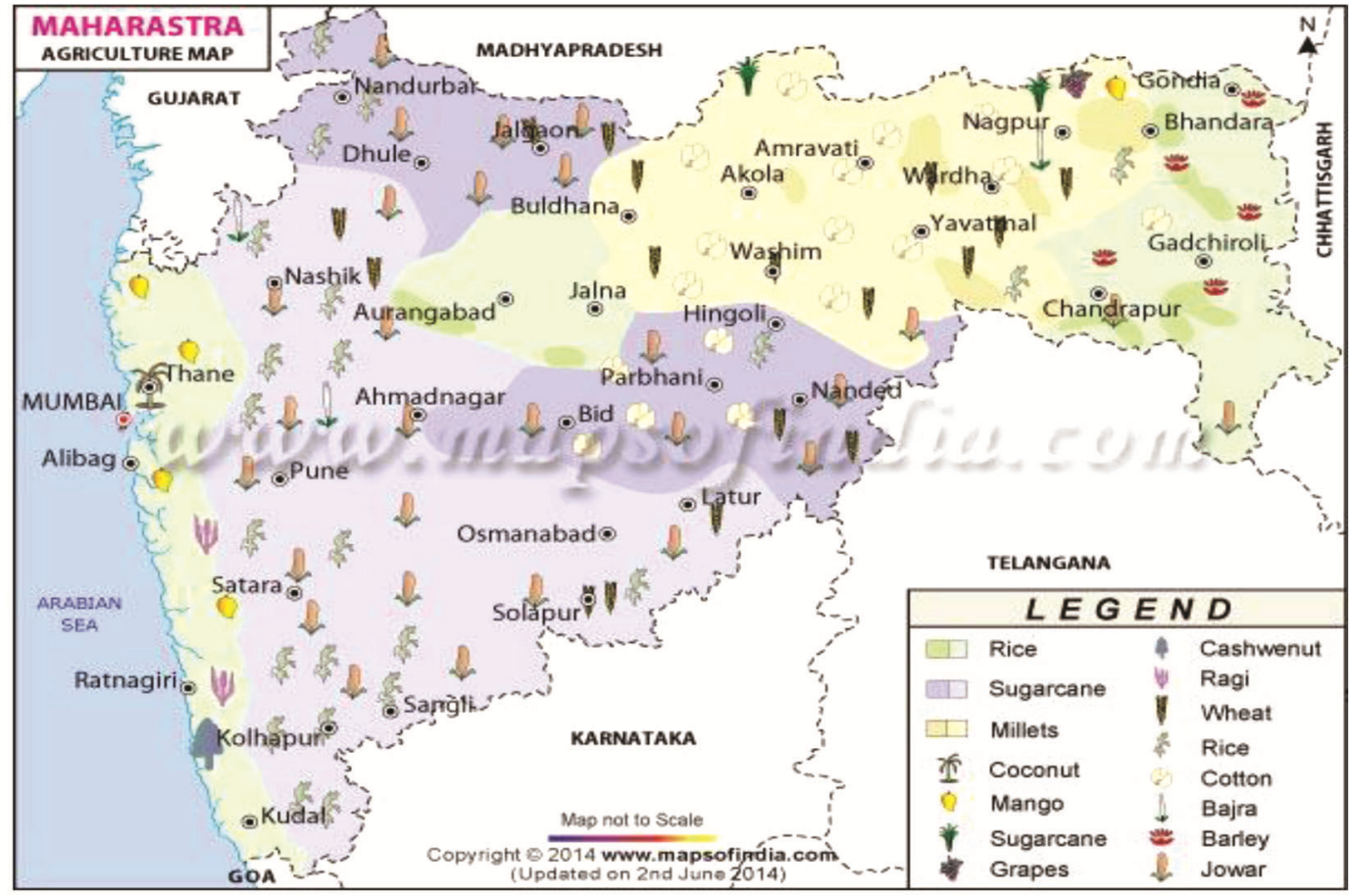

Figure 3. Major crops in Maharashtra (Source: Maps of India).

sugarcane, cotton and rice were obtained from agricultural and statistical reports of the Government of Maharash$\operatorname{tra}^{28,31}$.

(iii) The statistically downscaled MPI-ESM-MR (Max Plank Institute-Earth System Model-Medium Resolution) model from the archive of NEX-GDDP (NASA Earth Exchange-Global Daily Downscaled Products available at https://cds.nccs.nasa.gov/nex-gddp/) archive has been used. This is one of the best models which simulates the mean seasonal rainfall and temperature pattern over India reasonably well ${ }^{32,33}$. The model output is achieved by applying the bias-corrected spatial disaggregation method of statistical downscaling to the MPI-ESM-MR model from CMIP5 (Coupled Model Intercomparison Project 5). The resolution of this downscaled model is $0.25^{\circ} \times 0.25^{\circ}$ long./lat. The present century simulations are available over the globe for 1951-2005, while the future projections are available for two scenarios, viz. RCP4.5 and RCP8.5 for the period 2006-99. The variables available are daily precipitation, maximum and minimum temperature. In this study, we have examined the projected changes in crop production for two time slices-the 2040s (2031-60) and the 2080s (2070-99) with respect to the base period (1976-2005) under the RCP4.5 scenario.

\section{Methodology}

The simple regression technique has been applied to develop the relationship between annual crop production and climate parameters, rainfall, minimum and maximum temperature. We examined four different types of regression models to select the most suitable one for this study.

Multiple linear regression model:

$$
Y_{t}=\alpha_{0}+\alpha_{1} t+\alpha_{2} P_{t}+\alpha_{3} T_{t}+\alpha_{4} P_{t} T_{t}+\varepsilon
$$

The log-linear regression model:

$$
\log \left(Y_{t}\right)=\beta_{0}+\beta_{1} t+\beta_{2} P_{t}+\beta_{3} T_{t}+\beta_{4} P_{t} T_{t}+\varepsilon
$$

Polynomial regression model:

$$
Y_{t}=\lambda_{0}+\lambda_{1} t+\lambda_{2} P_{t}+\lambda_{3} P_{t}^{2}+\lambda_{4} T_{t}+\lambda_{5} T_{t}^{2}+\lambda_{6} P_{t} T_{t}+\varepsilon
$$

Log-polynomial regression model:

$$
\begin{aligned}
& \log \left(Y_{t}\right)=\mu_{0}+\mu_{1} t+\mu_{2} P_{t}+\mu_{3} P_{t}^{2}+\mu_{4} T_{t}+\mu_{5} T_{t}^{2} \\
& \quad+\mu_{6} P_{t} T_{t}+\varepsilon
\end{aligned}
$$

Here, $Y_{t}$ is the crop production in year $t$ (we have developed the equations for rice, sugarcane and cotton); $t$ the time trend variable to capture technological change; $P_{t}$ the average annual rainfall $(\mathrm{mm})$ per annum during 1980$2015 ; T_{t}$ is the average minimum or maximum temperature $\left({ }^{\circ} \mathrm{C}\right)$ during $1980-2015$ and $\varepsilon$ is the error term.

$\alpha \mathrm{s}, \beta \mathrm{s}, \lambda \mathrm{s}, \mu \mathrm{s}$ are unknown regression coefficients to be estimated. The estimated values of regression coefficients and projections of climate parameters were then used to project future crop production. We used the Akaike Information Criterion (AIC) to compare these 

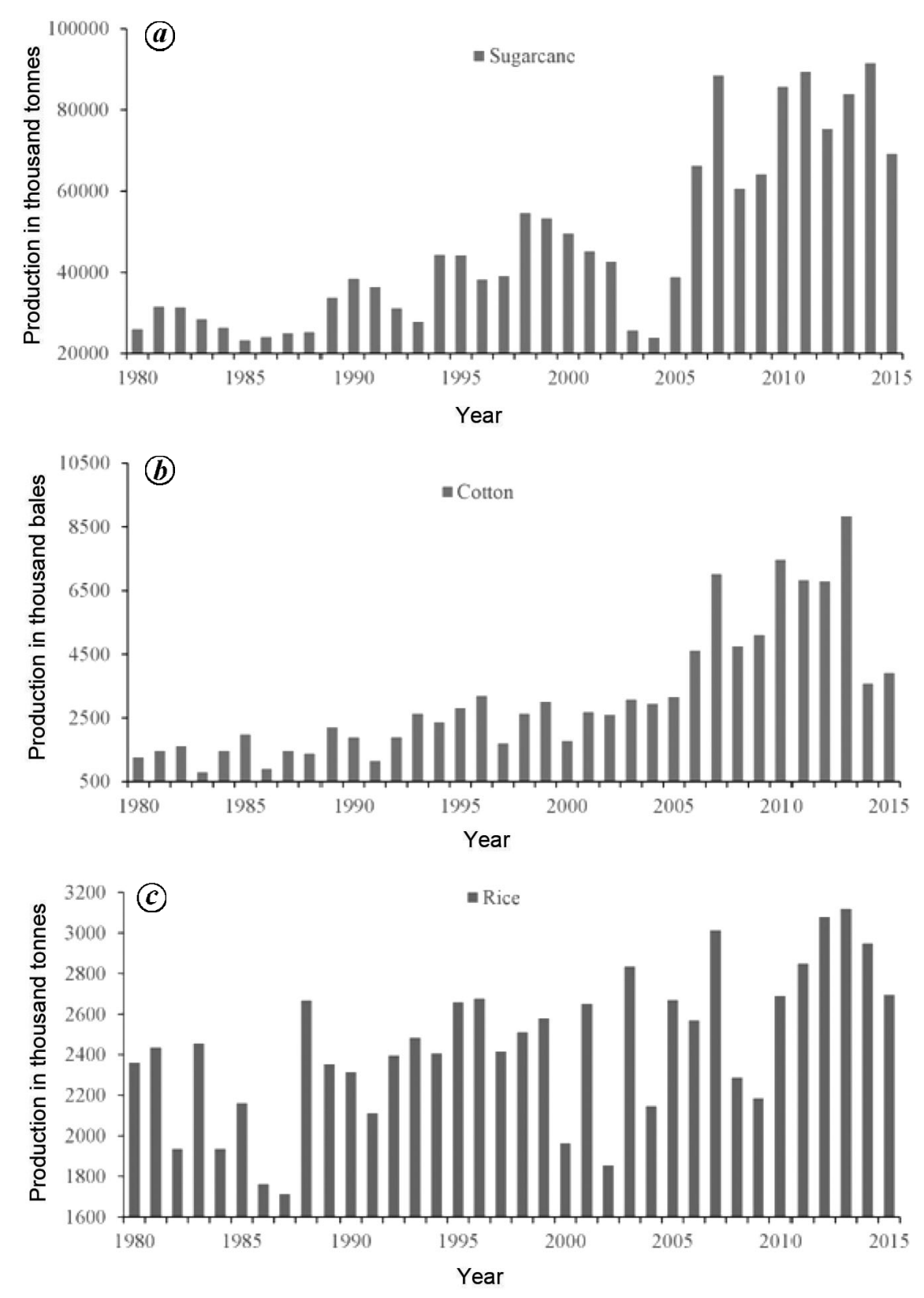

Figure 4. Time series of annual average production of (a) sugarcane, $(\boldsymbol{b})$ cotton and (c) rice for Maharashtra during 1980-2015.

four models. This method evaluates the regression models and shows the relatively best-fitting model for the given data ${ }^{34}$. By this criterion, the preferred model is the one with the lowest AIC value.

$$
\mathrm{AIC}=2 k-2 \ln (L),
$$

where $k$ is the number of estimated parameters in the model and $L$ is the maximum value of the likelihood function of the model.

With this criterion, eq. (4) is the best model. In order to obtain crop production values, we add the square of the error term and take the exponential of the total sum.

$$
y_{t}=\exp \left(\log \left(y_{t}\right)+\frac{s^{2}}{2}\right) \text {, }
$$

where $y_{t}$ is the projected crop production, and $s^{2}$ is the square of error (variance).

\section{Results and discussion}

\section{Regression analysis}

Using AIC, the log-polynomial regression model (eq. (4)) is the best to study the relationship between maximum 


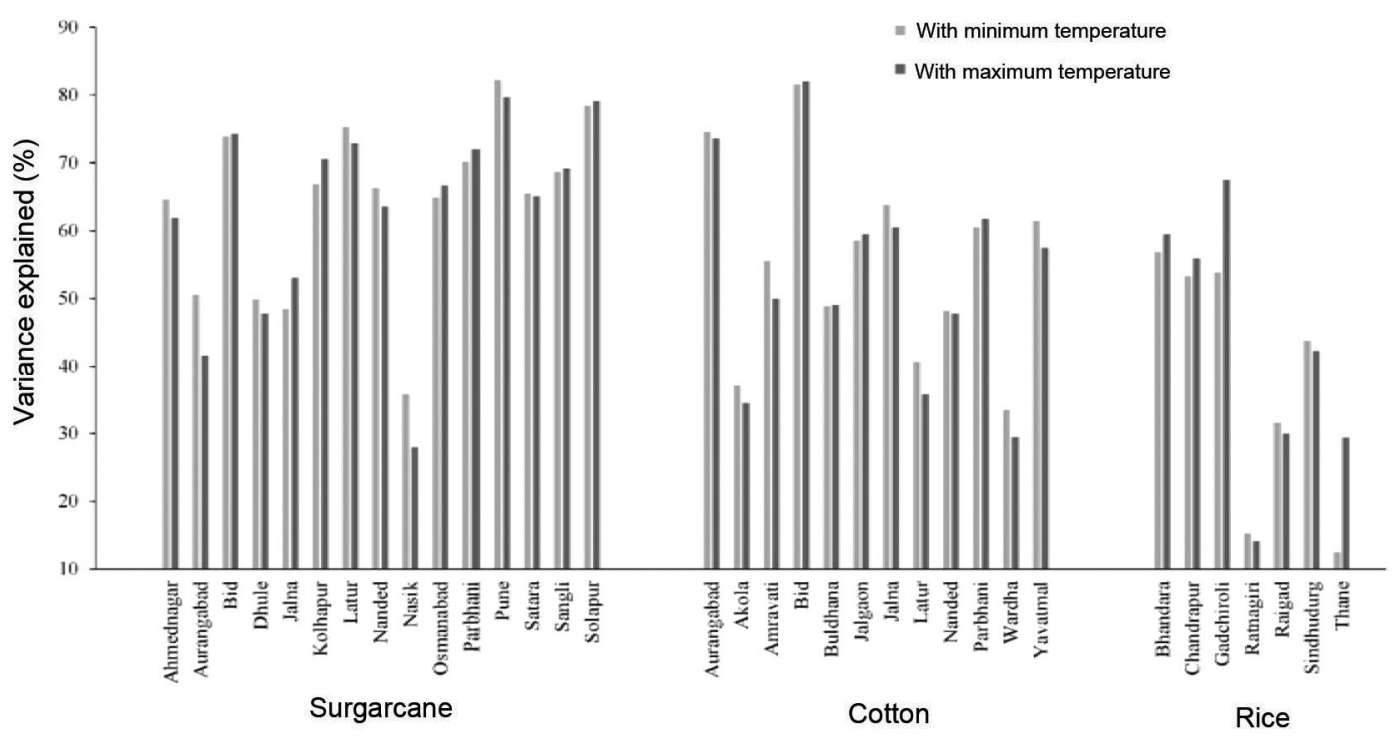

Figure 5. The variance (\%) explained by rainfall and minimum temperature (light bars), and rainfall and maximum temperature (dark bars) in the production of sugarcane, cotton and rice in various districts of Maharashtra.

Table 1. Districts having significant regression parameters in the production of sugarcane, cotton and rice using log-polynomial regression

\begin{tabular}{|c|c|c|c|}
\hline Parameters & Sugarcane & Cotton & Rice \\
\hline Trend & $\begin{array}{l}\text { Ahmednagar***, Dhule***, Kolhapur***, } \\
\text { Nasik***, Pune***, Sangli***, Satara***, } \\
\text { Aurangabad***, Bid***, Jalna***, Latur***, } \\
\text { Nanded***, Osmanabad***, Parbhani*** }\end{array}$ & $\begin{array}{l}\text { Aurangabad***, Bid***, Jalgaon***, } \\
\text { Jalna***, Nanded***, Parbhani***, } \\
\text { Akola***, Amravati***, Buldhana***, } \\
\text { Nagpur***, Wardha***, Yavatmal***, } \\
\text { Latur** }\end{array}$ & $\begin{array}{l}\text { Ratnagiri***, Sindhudurg***, } \\
\text { Bhandara***, Gadchiroli***, } \\
\text { Raigad** }\end{array}$ \\
\hline$P\left(\right.$ with $\left.T_{\min }\right)$ & $\begin{array}{l}\text { Ahmednagar**, Aurangabad**, Bid**, } \\
\text { Latur**, Nasik*, Pune*, Osmanabad* }\end{array}$ & - & Thane**, Chandrapur** \\
\hline$P\left(\right.$ with $\left.T_{\max }\right)$ & Bid**, Jalna*, Latur*, Osmanabad* & - & Chandrapur**, Gadchiroli* \\
\hline$P^{2}$ (with $\left.T_{\min }\right)$ & Ahmednagar** & Jalgaon $* * *$ & $\begin{array}{l}\text { Bhandara***, Chandrapur***, } \\
\text { Gadchiroli*** }\end{array}$ \\
\hline$P^{2}$ (with $T_{\max }$ ) & Kolhapur*, Bid* & Jalgaon $* * *$ & $\begin{array}{l}\text { Bhandara***, Chandrapur***, } \\
\text { Gadchiroli** }\end{array}$ \\
\hline$T_{\min }$ & - & Aurangabad*, Amravati* & - \\
\hline$T_{\min }^{2}$ & - & Amravati** & - \\
\hline$T_{\max }$ & Kolhapur* & - & - \\
\hline$T_{\max }^{2}$ & & - & - \\
\hline$P \times T_{\min }$ & $\begin{array}{l}\text { Latur***, Ahmednagar**, Aurangabad**, } \\
\text { Bid**, Nasik*, Pune*, Nanded*, } \\
\text { Osmanabad* }\end{array}$ & Amravati** & - \\
\hline$P \times T_{\max }$ & $\begin{array}{l}\text { Bid**, Kolhapur*, Jalna*, Latur*, } \\
\text { Osmanabad*, Parbhani* }\end{array}$ & - & Thane**, Gadchiroli** \\
\hline
\end{tabular}

${ }^{* * *} p<0.01,{ }^{* *} p<0.05,{ }^{*} p<0.1 . P$, Rainfall; $T_{\min }$, Minimum temperature; $T_{\max }$, Maximum temperature. $P$ (with $T_{\min }$ ), Regression model including rainfall and minimum temperature. $P$ (with $T_{\max }$ ), Regression model including rainfall and maximum temperature.

and minimum temperature, rainfall and crop production. $R^{2}$, the square of multiple correlation coefficient, gives the proportion of total variance in crop production explained by the parameters (Figure 5). The high proportion of variation explained by rainfall and maximum and minimum temperature shows that crop production is highly related to these parameters. Table 1 shows the districts having significant regression coefficients with the climate parameters. The relationship is particularly strong in the drought-prone districts of Marathwada and Madhya Maharashtra. Sugarcane production over Nasik and cotton production over Latur are not much related to 
RESEARCH ARTICLES

Table 2. F-test for significance of regression with different crops

\begin{tabular}{|c|c|c|c|c|c|c|c|c|}
\hline \multirow[b]{2}{*}{ District } & \multicolumn{2}{|c|}{ Sugarcane } & \multirow[b]{2}{*}{ District } & \multicolumn{2}{|c|}{ Cotton } & \multirow[b]{2}{*}{ District } & \multicolumn{2}{|c|}{ Rice } \\
\hline & $T_{\min }$ & $T_{\max }$ & & $T_{\min }$ & $T_{\max }$ & & $T_{\min }$ & $T_{\max }$ \\
\hline Ahmednagar & $8.83 * * *$ & $7.85 * * *$ & Aurangabad & $14.18 * * *$ & $13.47 * * *$ & Bhandara & $6.39 * * *$ & $7.01 * * *$ \\
\hline Aurangabad & $6.06 * * *$ & $4.83 * * *$ & Akola & $2.86^{* *}$ & $2.54 * *$ & Chandrapur & $5.32 * * *$ & $5.93 * * *$ \\
\hline Bid & $4.95 * * *$ & $3.44 * *$ & Amravati & $13.69 * * *$ & $13.99 * * *$ & Garhchiroli & $5.27 * * *$ & $9.33 * * *$ \\
\hline Dhule & $4.80 * * *$ & $4.43 * * *$ & Beed & $21.45 * * *$ & $21.96 * * *$ & Ratnagiri & 0.87 & 0.79 \\
\hline Jalna & $4.39 * * *$ & $5.29 * * *$ & Buldana & $4.63 * * *$ & $4.67 * * *$ & Raigarh & $2.24 *$ & $2.07 *$ \\
\hline Kolhapur & $9.77 * * *$ & $11.55 * * *$ & Jalgaon & $6.83 * * *$ & $7.1 * * *$ & Sindhudurg & $3.5 * *$ & $3.29 * *$ \\
\hline Latur & $13.7 * * *$ & $12.1 * * *$ & Jalna & $8.22 * * *$ & $7.15 * * *$ & Thane & 0.69 & $2.01 *$ \\
\hline Nanded & $9.51 * * *$ & $8.45 * * *$ & Latur & $2.97 *$ & 2.413 & & & \\
\hline Nasik & $2.69 * *$ & 1.88 & Nanded & $4.5 * * *$ & $4.43 * * *$ & & & \\
\hline Osmanabad & $8.93 * * *$ & $9.66 * * *$ & Parbhani & $7.34 * * *$ & $7.83 * * *$ & & & \\
\hline Parbhani & $11.40 * * *$ & $12.42 * * *$ & Wardha & $2.43 * *$ & $2.02 * *$ & & & \\
\hline Pune & $22.3 * * *$ & $18.96 * * *$ & Yavatmal & $7.73 * * *$ & $6.55 * * *$ & & & \\
\hline Satara & $9.18 * * *$ & $8.99 * * *$ & & & & & & \\
\hline Sangli & $10.6 * * *$ & $10.88 * * *$ & & & & & & \\
\hline Solapur & $17.5 * * *$ & $18.3 * * *$ & & & & & & \\
\hline
\end{tabular}

*** $p<0.01,{ }^{* *} p<0.05, * p<0.1 . T_{\min }$, Regression with rainfall and minimum temperature. $T_{\max }$, Regression with rainfall and maximum temperature.
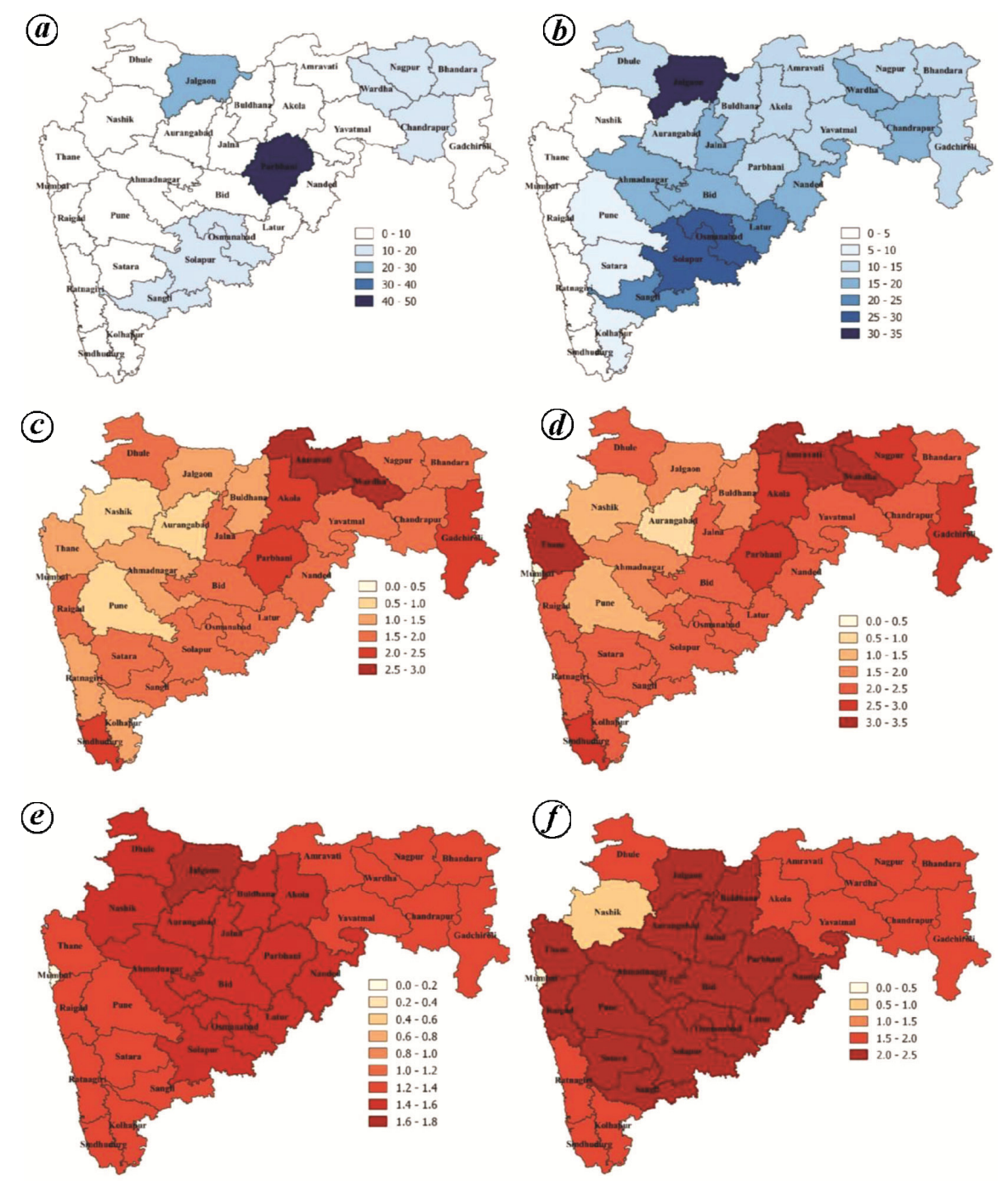

Figure 6. Percentage change in annual rainfall, change in minimum temperature $\left({ }^{\circ} \mathrm{C}\right)$ and change in maximum temperature $\left({ }^{\circ} \mathrm{C}\right)$ for $1976-2005$ under RCP4.5 during 2040s $(\boldsymbol{a}, \boldsymbol{c}, \boldsymbol{e})$ respectively and $2080 \mathrm{~s}(\boldsymbol{b}, \boldsymbol{d}, \boldsymbol{f})$ respectively. 
(a)

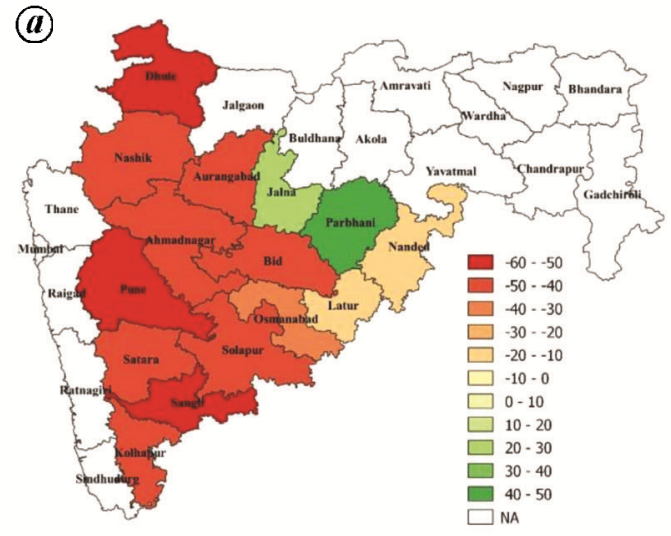

(c)

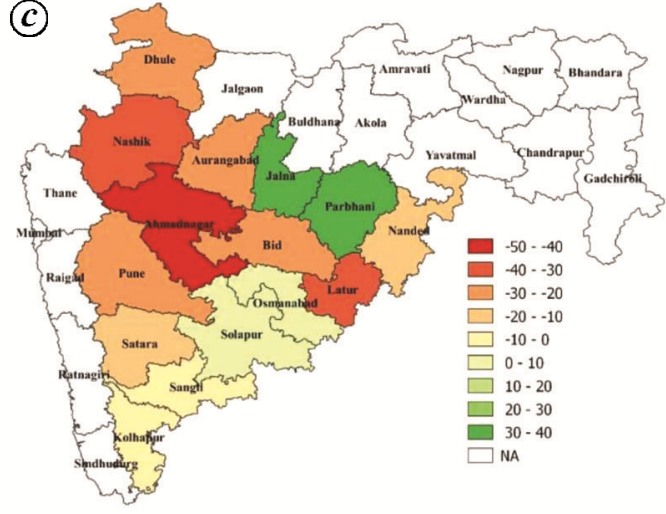

(b)

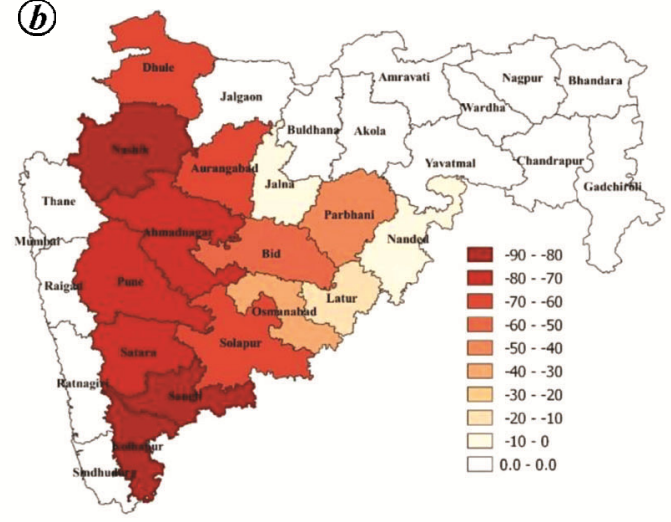

(d)

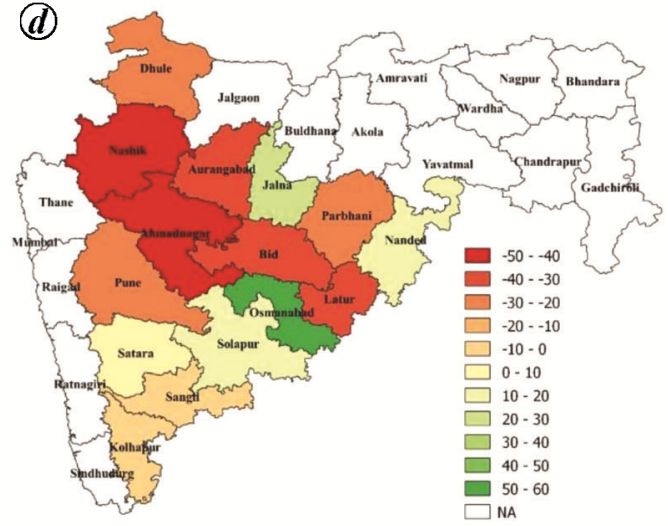

Figure 7. Percentage change in sugarcane production with change in rainfall and maximum temperature during (a) 2040s and (b) 2080s and with change in rainfall and minimum temperature during (c) 2040s and (d) 2080s for 1976-2005 under RCP4.5.

maximum temperature. Also, rice production over Ratnagiri has no relationship with minimum/maximum temperature and that over Thane is associated with maximum temperature only (Figure 5). Table 2 gives the $F$ values for significant regression equations for different districts.

\section{Climate change impact on crop production}

The projected changes in rainfall and minimum and maximum temperature have been computed from the MPIESM-MR simulations under climate change scenario RCP4.5 for two time-epochs, the 2040s and 2080s, with respect to the baseline period 1980s. These projected changes in the parameters over various districts and the estimated regression coefficients are introduced in eq. (2) to estimate the projected changes in the production of sugarcane, cotton and rice. All projections are with respect to the base period 1976-2005. Similar projections for crop production have been given for Tamil $\mathrm{Nadu}^{35}$ and Sub-Saharan Africa ${ }^{36}$.

Projected changes in precipitation and temperature under RCP4.5: $\mathrm{RCP} 4.5$ is a more realistic future scenario, where the total radiative forcing of the atmosphere reaches
$4.5 \mathrm{~W} / \mathrm{m}^{2}$ towards the end of the century ${ }^{37}$. The projected changes in annual rainfall show a general increase in both the time periods, viz. 2040s (Figure $6 a$ ) and 2080s (Figure $6 \mathrm{~b}$ ). In $2040 \mathrm{~s}$, rainfall increases up to $50 \%$, maximum over Parbhani, while towards the end of the century the increase is up to $30 \%$, more pronounced over the dry districts of Solapur, Osmanabad and Jalgaon.

The annual average minimum temperature shows consistent warming over all districts of Maharashtra; maximum warming is projected over the northern parts of Vidarbha (Figure $6 c$ and $d$ ). The minimum temperatures shows warming of the order of $3^{\circ}$ to $3.5^{\circ} \mathrm{C}$. The minimum temperature shows more warming than the maximum temperature (Figure $6 e$ and $f$ ) over the entire state.

Projected changes in sugarcane production: The regression results show that sugarcane production is negatively related to the increase in daytime temperature, but it has a positive relationship with rainfall. The projections indicate that the rise in maximum temperature may reduce production by $40-80 \%$ during 2040 s and by 60 $90 \%$ during 2080s (Figure 7). The major decrease in 2040s is over the districts of Marathwada, viz. Latur, Nanded, Parbhani and Jalna, while in 2080s sugarcane production is projected to decrease over almost all the districts. The rise in minimum temperature may reduce 

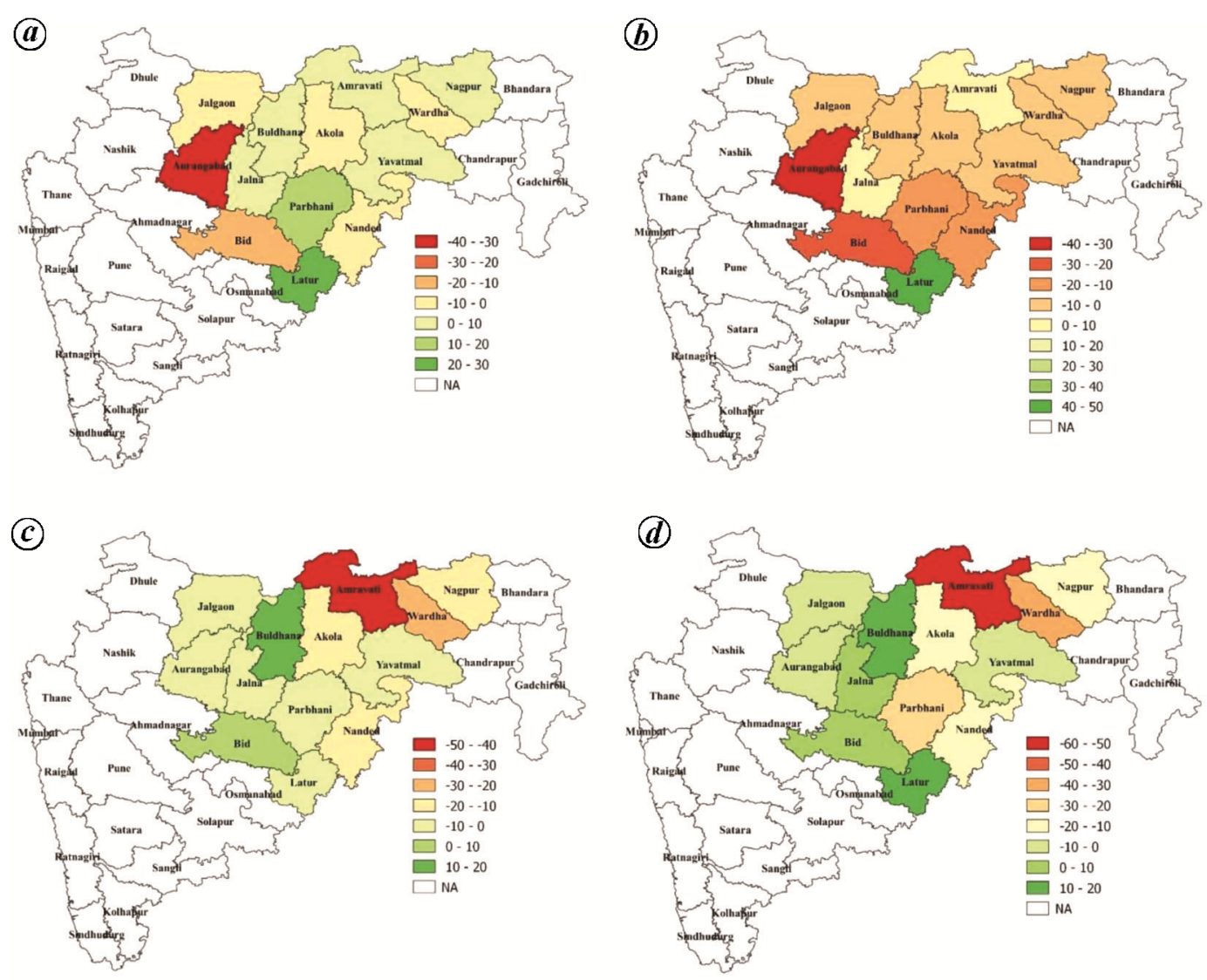

Figure 8. Percentage change in cotton production with change in rainfall and maximum temperature during (a) 2040s and (b) 2080s and with change in rainfall and minimum temperature during (c) 2040s and (d) 2080s for 1976-2005 under RCP4.5.

sugarcane production by $20-40 \%$ in Madhya Maharashtra during $2040 \mathrm{~s}$, and a decrease of $20-60 \%$ in $2080 \mathrm{~s}$. Despite the loss in production in majority of the districts, some regions such as Parbhani, Osmanabad, Solapur and Jalna have shown an overall increase of $20-40 \%$, possibly due to increase in seasonal rainfall in these regions (Figure 7).

Projected changes in cotton production: Cotton production and climate variables show a strong relationship at the district level. The production is projected to increase by $20-30 \%$ during 2040 s and relatively decrease by $20 \%$ during $2080 \mathrm{~s}$ in majority of the districts with increase in maximum temperature. The production may decrease largely in 2080s. The increase in minimum temperature marks an overall surge in production by $10-20 \%$ with an exception of Amravati district, which indicates major loss by $50-60 \%$ (Figure 8 ).

Projected changes in rice production: The regression results show that rice crop production is sensitive to changes in night-time temperature. Projections indicate a decrease in rice production in the districts of Kokan, except for Ratnagiri by $15-25 \%$ and $10-40 \%$ with the rise in maximum temperature during 2040s and 2080s respectively, while eastern Vidarbha shows a decrease of $5-10 \%$ during 2040 s and increase of $10 \%$ during 2080 s. The increase in minimum temperature marks an overall rise of 5-10\% in Kokan and East Vidarbha during 2040s. At the end of the century, an overall increase of $5-10 \%$ in rice production is projected (Figure 9).

\section{Conclusion}

This study presents the possible impact of climate change on the production of rice, sugarcane and cotton over various districts of Maharashtra. The statistically downscaled MPI-ESM-MR model from the NEX-GDDP archive of NASA has been used, and the projections have been considered under the RCP4.5 scenario.

The districts of Marathwada and Western Vidarbha in Maharashtra are drought-prone areas. Despite this, crops like sugarcane which consume more water are grown in these regions. The continuation of this practice in the future might cause severe water stress in the regions, which may lead to more frequent droughts. Based on RCP4.5 projections, variability in rainfall and temperature is likely to be more in Marathwada and Vidarbha. This calls for stress-tolerant crop breeds which are resilient to frequent 

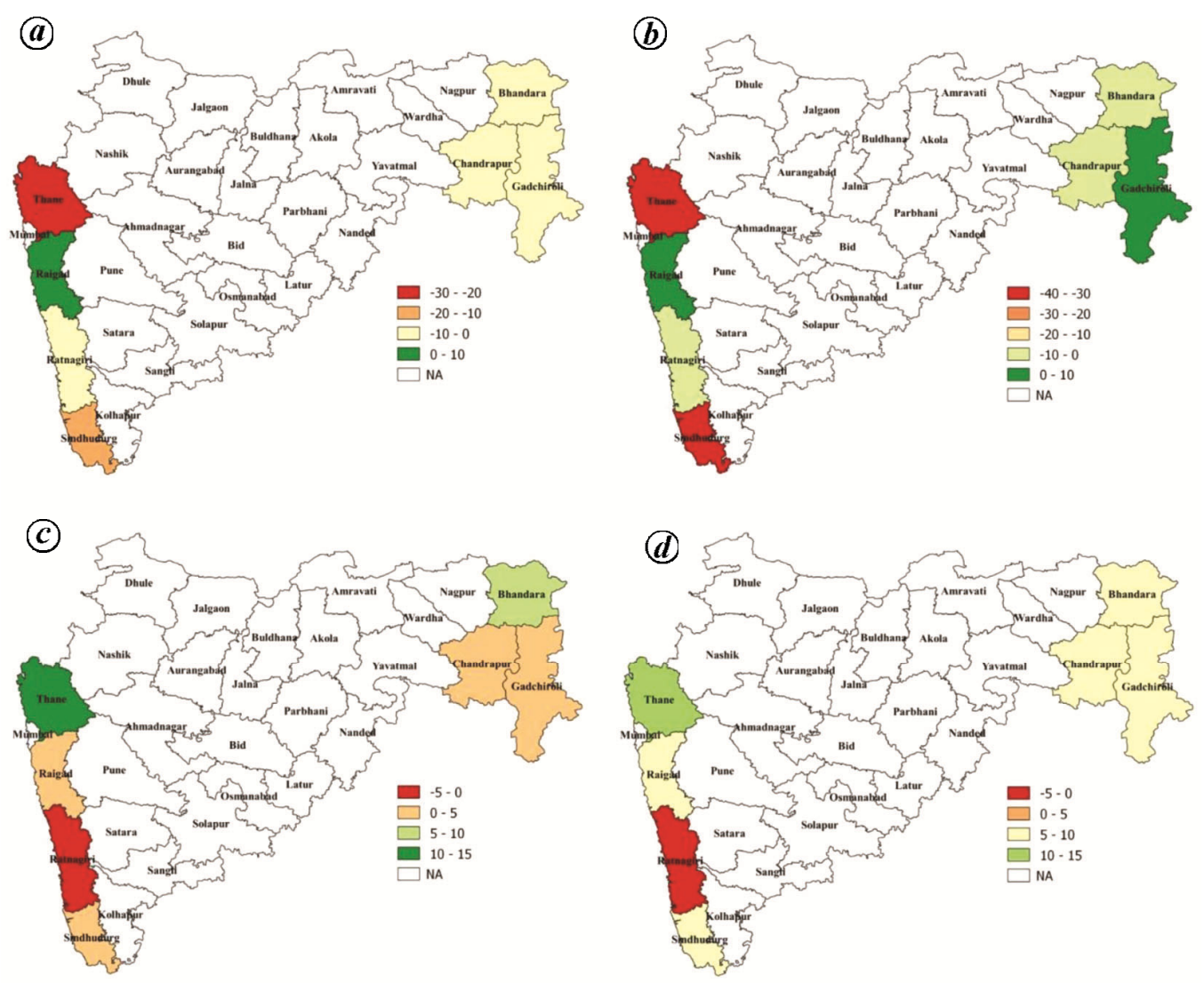

Figure 9. Percentage change in rice production with change in rainfall and maximum temperature during (a) 2040s and (b) 2080s, and with change in rainfall and minimum temperature during (c) 2040s and (d) 2080s for 1976-2005 under RCP4.5.

droughts and drastic changes in minimum and maximum temperature. The projections indicate that the rise in minimum temperature is more pronounced compared to maximum temperature. The minimum (night-time) temperature plays a vital role in plant growth by regulating the respiration rate.

Future projections of rainfall and minimum and, maximum temperature for Maharashtra based on RCP4.5 show an increase in rainfall over the districts by $10-50 \%$ during 2040s and 2080s. The rise in minimum temperature is more prominent in the Vidarbha region $\left(2^{\circ}\right.$ $3.5^{\circ} \mathrm{C}$ ), while the increase in maximum temperature is likely to be prominent in Madhya Maharashtra and Marathwada $\left(1.5^{\circ}-2.5^{\circ} \mathrm{C}\right)$

The log-polynomial regression model (eq. (4)) has been used to study the impact of changing climate on various crops. The regression results show that rice production is sensitive to changes in night-time temperature. Sugarcane production is negatively related to the rise in daytime temperature, but it also has a positive relationship with rainfall. Cotton production and climate variables show a strong relationship at the district level. Like sugarcane, cotton is also sensitive to day-time temperature. The variation in crop production due to rainfall, and minimum and maximum temperature is particularly high; $70-85 \%$, in the drought-prone districts of Madhya Maharashtra and Marathwada while for cotton production it ranges from $30 \%$ to $80 \%$. For rice production in Kokan, the variance is $20-40 \%$ and in eastern Vidarbha it is as high as $70 \%$. The $F$-test shows that the regression coefficients are significant at $1 \%$ and $5 \%$.

Based on the changes in these climate parameters, sugarcane production may reduce by $40-80 \%$ in major parts of Madhya Maharashtra and Marathwada during 2040 s, and by $60-90 \%$ during 2080 s. On the other hand, cotton production is projected to increase by $20-40 \%$ in various districts of Vidarbha and Aurangabad during 2040 s and reduce by $20-50 \%$ during 2080 s. The projections for rice production in Konkan indicate a reduction by $15-25 \%$ and $10-40 \%$ during 2040 s and 2080 s respectively. For Eastern Vidarbha, the decrease is projected to be $5-10 \%$ during 2040 s and increase of $10 \%$ during 2080s. This analysis is based on only one model and hence the projections need to be used with caution. In future, a large number of models will be analysed in order to get a range of uncertainty in model projections and to gain more confidence.

1. Mall, R. K., Singh, R., Gupta, A., Srinivasan, G. and Rathore, L. S., Impact of climate change on Indian agriculture: a review. Climatic Change, 2006, 78(2-4), 445-478.

2. Hingane, L. S., Rupa Kumar, K. and Ramana Murthy, Bh. V., Long-term trends of surface air temperature in India. J. Climatol., $1985, \mathbf{5}, 521-528$. 
3. Srivastava, H. N., Dewan, B. N., Dikshit, S. K., Rao, G. S. P., Singh, S. S. and Rao, R., Decadal trends in climate over India. Mausam, 1992, 43, 7-20.

4. Rupa Kumar, K., Krishna Kumar, K. and Pant, G. B., Diurnal asymmetry of surface temperature trends over India. Geophys. Res. Lett., 1994, 21, 677-680.

5. De, U. S. and Mukhopadhyay, R. K., Severe heat wave over the Indian subcontinent in 1998, in perspective of global climate. Curr. Sci., 1998, 75(12), 1308-1311.

6. Pant, G. B., Rupa Kumar, K. and Borgaonkar, H. P., Climate and its long-term variability over the western Himalaya during the past two centuries. In The Himalayan Environment (eds Dash, S. K. and Bahadur, J.), New Age International (P) Limited, New Delhi, 1999, pp. 172-184.

7. Singh, N. and Sontakke, N. A., On climatic fluctuations and environmental changes of the Indo-Gangetic plains, India. Climatic Change, 2002, 52, 287-313.

8. Singh, R. S., Narain, P. and Sharma, K. D., Climate changes in Luni river basin of arid western Rajasthan (India). Vayu Mandal, 2001, 31(1-4), 103-106.

9. Mooley, D. A. and Parthasarathy, B., Fluctuations of all India summer monsoon rainfall during 1871-1978. Climatic Change, 1984, 6, 287-301

10. Thapliyal, V. and Kulshrestha, S. M., Climate changes and trends over India. Mausam, 1991, 42, 333-338.

11. Pant, G. B. and Rupa Kumar, K., In Climates of South Asia, John Wiley, West Sussex, UK, 1997, p. 320.

12. Stephenson, D. B., Douville, H. and Rupa Kumar, K., Searching for a fingerprint of global warming in the Asian summer monsoon. Mausam, 2001, 52(1), 213-220.

13. IPCC AR5. In Climate Change 2013: Impacts, Adaptation, and Vulnerability. Part B: Regional Aspects. The Contribution of Working Group II to the Fifth Assessment Report of the Intergovernmental Panel on Climate Change (eds Barros, V. R. et al.), Cambridge University Press, Cambridge, UK, 2014, pp. 13271370 .

14. UN, World population prospects: the 2015 revision, key findings and advance tables, Working Paper No. ESA/P/WP.241, Department of Economic and Social Affairs, Population Division, United Nations, 2015.

15. IPCC AR5, Food security, and food production systems. In Climate Change 2013: Impacts, Adaptation, and Vulnerability. Part A: Global and Sectoral Aspects. The Contribution of Working Group II to the Fifth Assessment Report of the Intergovernmental Panel on Climate Change (eds Field, C. B. et al.), Cambridge University Press, Cambridge, UK, 2014, pp. 485-533.

16. Abrol, Y. P. and Ingram, K. T., Effects of high day and night temperatures on growth and yields of some crop plants. In Global Climate Change and Agricultural Production, FAO and John Wiley, Chichester, 1996, pp. 122-140.

17. Mackill, D. J., Coffman, W. R. and Rutger, L. J., Pollen shedding and combining ability for high temperature tolerance in rice. Crop Sci., 1982, 20, 730-733.

18. Zheng, K. L. and Mackill, D. T., Effect of high temperature on anther dehiscence and pollination in rice. Sabrao J., 1982, 14, 61-66.

19. Bowman, W. D. and Strain, B. R., Interaction between $\mathrm{CO}_{2}$ enrichment and salinity stress in the $\mathrm{C} 4$ non-halophyte Andropogon glomeratus (Walter) BSP. Plant, Cell Environ., 1987, 10, 267-270.

20. Sombroek, W. G. and Brinkman, R., The effects of global change on soil conditions in relation to plant growth and food production. In Global Climate Change and Agricultural Production, FAO and John Wiley, 1996, pp. 49-64.

21. Bazzaz, F. and Sombroek, W., Global climatic change and agricultural production: an assessment of current knowledge and critical gaps. In Global Climate Change and Agricultural Production, FAO and John Wiley, 1996, pp. 319-330.
22. Aggarwal, P. K. and Mall, R. K., Climate change and rice yields in diverse agro-environments of India: effect of uncertainties in scenarios and crop models on impact assessment. Climatic Change, 2002, 52(3), 331-343.

23. Geethalakshmi, V. et al., Climate change impact assessment and adaptation strategies to sustain rice production in Cauvery basin of Tamil Nadu. Curr. Sci., 2011, 101(3), 342-347.

24. Hebbar, K. B., Predicting cotton production using Infocrop-cotton simulation model, remote sensing and spatial agro-climatic data. Curr. Sci., 2008, 95(11), 1570-1579.

25. Saseendran, S. A., Singh, K. K., Rathore, L. S., Singh, S. V. and Sinha, S. K., Effects of climate change on rice production in the tropical humid climate of Kerala, India. Climatic Change, 2000, 44, 495-514.

26. Murthy, V. R. K., Crop growth modeling and its applications in agricultural meteorology, In Satellite Remote Sensing and GIS Applications in Agricultural Meteorology. WMO, Geneva, 2004, pp. 235-261.

27. Bishoyi Ratna, S., Summer monsoon rainfall variability over Maharashtra, India. Pure Appl. Geophys., 2012, 169(2012), 259273.

28. GoI, Pocket Book of Agricultural Statistics, Directorate of Economics and Statistics, Department of Agriculture, Cooperation \& Farmers Welfare, Government of India, 2016.

29. Murthy, V. R. K., Basic Principles of Agricultural Meteorology, BS Publications, Hyderabad, 2002, pp. 76-80; 186-188.

30. Position paper - Droughts and sugar industry in Maharashtra - are we learning from history? India Water Partnership, 2016.

31. Season and crop reports of Maharashtra, Department of Economics and Statistics, Government of Maharashtra, 1980-2015.

32. Kripalani, R. H. et al., South Asian summer monsoon precipitation variability: coupled climate model simulations and projections under IPCC AR4. Theoret. Appl. Climatol., 2007, 90, 133-159.

33. Sabade, S. S. et al., Projected changes in South Asian summer monsoon by multi-model global warming experiments. Theor. Appl. Climatol., 2011, 103, 543-565.

34. Akaike, H., A new look at the statistical model identification. IEEE Trans. Autom. Control, 1974, 19(6), 716-723; doi:10.1109/ TAC.1974.1100705.

35. Saravana Kumar, V., Impact of climate change on yield of major food crops in Tamil Nadu, India, Working Paper No. 91-1, SANDEE, 2015.

36. Lobell, D. B. and Burke, M. B., On the use of statistical models to predict crop yield response to climate change. In Agricultural and Forest Meteorology, Elsevier, 2010, 150, 1443-1452.

37. van Vuuren et al., The representative concentration pathways: an overview. Climatic Change, 2011, 109, 5-31; doi:10.1007/ s10584-011-0148-z

38. R Core Team, R: A language and environment for statistical computing. R Foundation for Statistical Computing, Vienna, Austria, 2018; https://www.R-project.org/

39. QGIS Development Team, QGIS Geographic Information System. Open Source Geospatial Foundation Project, 2018; http://qgis.osgeo.org/

ACKNOWLEDGEMENTS. We thank Dr K. C. Sinha Rey (Savitribai Phule Pune University) for support. We also thank MOEF and CC for providing grant for the research project under preparation of India's Third National Communication (NATCOM-III) to UNFCCC. We thank developers of R-software ${ }^{38}$ and QGIS $^{39}$, as well as to NASA for providing statistically downscaled data.

Received 13 December 2018; revised accepted 26 November 2019

doi: $10.18520 / \mathrm{cs} / \mathrm{v} 118 / \mathrm{i} 8 / 1235-1245$ 